\title{
Mikroelem-terhelés hatása a spenótra karbonátos csernozjom talajon
}

\author{
${ }^{1}$ KÁDÁR IMRE, ${ }^{2}$ DAOOD HUSSEIN és ${ }^{3}$ RADICS LÁSZLÓ \\ ${ }^{1}$ MTA Talajtani és Agrokémiai Kutatóintézet, Budapest \\ ${ }^{2}$ Központi Élelmiszeripari Kutatóintézet, Lipidlaboratórium, Budapest \\ ${ }^{3}$ Szent István Egyetem Kertészettudományi Kar, Budapest
}

A spenót (Spinacia oleracea L.) fontos hazai zöldségnövényünk. Levelének szárazanyagában a fehérje 20-30 \% körüli, emellett jelentős vitamin- és ásványi-anyag készlettel rendelkezik. Kedvelt bébiétel, a hütő- és konzerviparnak is alapanyagául szolgál. Elö-Ázsiából származik, Európába a VIII.-IX. században Spanyolországon keresztül a mór hódítással jutott be. Kétszikü egyéves kultúra. Fő- és oldalgyökérzete sekélyen helyezkedik el a talajban. Tenyészideje is rövid, ezért víz- és tápanyagigényesnek minősül (CSELÖTEI et al., 1993; BALÁZS, 1994).

BERGMANN (1988) szerint az éppen kifejlett fiatal spenótlevél összetétele jól tükrözi a növény tápláltsági állapotát és az alábbi koncentrációkkal jellemezhető: N 3,5-5,0 \%, K 3,5-5,3 \%, Ca 0,60-1,20 \%, P 0,40-0,60 \%, Mg 0,350,80\%, Mn 40-100 mg/kg, B 40-80 mg/kg, Zn 20-70 mg/kg, Cu 7-15 mg/kg, ill. Mo 0,30-1,00 mg/kg szárazanyagra vetítve. TERBE (1994) a 10 t zöld levéltermés elemigényét $35 \mathrm{~kg} \mathrm{~N}, 18 \mathrm{~kg} \mathrm{P}_{2} \mathrm{O}_{5}$ és $52 \mathrm{~kg} \mathrm{~K}_{2} \mathrm{O}$ mennyiségre becsüli. FiLIUS (1994) $80 \mathrm{~kg} \mathrm{~N}, 16 \mathrm{~kg} \mathrm{P}_{2} \mathrm{O}_{5}$ és $78 \mathrm{~kg} \mathrm{~K}_{2} \mathrm{O}$ tápelemigénnyel számol a 10 t/ha körüli termésre.

A leveles zöldségféléknek, különösen a salátának és a spenótnak nemkívánatosan nagy lehet az oxálsav-, nitrát- és károselem-akkumulációja (BERGMANN, 1988; LEHOCZKY et al., 1996, 1998; SIMON, 1998). MARSCHNER (1985) vizsgálatai szerint a friss spenótlevél $\mathrm{NO}_{3}$-koncentrációja $349-3890 \mathrm{mg} / \mathrm{kg}$ között ingadozhat a termesztési körülményektől függően. A határérték felnőttek számára $1200-1500 \mathrm{mg} / \mathrm{kg}$ a legtöbb európai országban, míg a csecsemőtápszerben $250 \mathrm{mg} \mathrm{NO} / \mathrm{kg}$ engedélyezett. Az $1500 \mathrm{mg} / \mathrm{kg}$ friss anyagra megadott $\mathrm{NO}_{3}, 10 \%$ körüli szárazanyag-tartalom esetén, 1,5\% $\mathrm{NO}_{3}$-ot, ill. $0,34 \% \mathrm{NO}_{3}$ $\mathrm{N}-\mathrm{t}$ jelenthet.

A káros elemek közül a kadmium került a figyelem középpontjába humántoxikológiai jellege miatt. BINGHAM és munkatársai (1975) kísérleteiben az 
Egyesült Államokban a spenót levelének Cd-tartalma a $160 \mathrm{mg} / \mathrm{kg}$ értéket is elérte szárazanyagban ott, ahol a kalászosok szemtermésében mindössze néhány $\mathrm{mg} / \mathrm{kg}$ mennyiség volt kimutatható. A kaliforniai tenyészedény-kísérletek meszes vályog talajához $1 \% 0,1 \%$ Cd-tartalmú szennyvíziszapot kevertek, így 10 $\mathrm{mg} / \mathrm{kg}$ Cd-készlettel rendelkeztek.

Az európai szerzők is kiemelik a spenót levelének elemdúsulását. VERLOO és WILLAERT (1990) Belgiumban a növénybeni/talajbani koncentrációnövekedés hányadosaként ismert transzfer koefficienst a kadmiumra 5,2, cinkre 2,0, nikkelre és rézre 0,5 értékben adja meg a spenót esetében. SAUERBECK (1982, 1991) Németországban erre a dúsulási/áthasonulási faktorra 1-10 értéket közöl a kadmium, cink, tallium, molibdén, valamint 0,1-1,0 értéket a réz és nikkel esetén. A nagyobb dúsulási hányadosok a leveles zöldségekre vonatkoznak.

A spenót károselem-forgalmáról kevés hazai adattal rendelkezünk, ezért szabadföldi tartamkísérletben vizsgáltuk a mikroelem-terhelés hatását a spenót termésére, gyomborítottságára, ásványi összetételére, elemfelvételére és némely szerves összetevő alakulására.

\section{Anyag és módszer}

A kísérletben végzett müveletekről és megfigyelésekről az 1. táblázat tájékoztat. A vetés április 17-én történt szemenkénti vetőgéppel, Matador fajtával, $20 \mathrm{~kg} /$ ha vetőmaggal, $2 \mathrm{~cm}$ mélységre. A sortáv $12 \mathrm{~cm}$, a csíraszám $22 \mathrm{db} / \mathrm{fm}$ volt. Május 12-én parcellánként gyomfelvételezést végeztünk és a spenót állományát is bonitáltuk fejlettségre. Június 3-án $60 \mathrm{db}$ levelet gyüjtöttünk parcellánként a zöld levéltermés mennyiségének és összetételének megállapítására. Július 23-án a légszáraz szár- és magtermést takarítottuk be, ill. ezt megelőzően az állományt ismét bonitáltuk fejlettségre vizuálisan. A szár- és magtermést a parcellánként vett 8-8 fm-es mintakévék anyagából állapítottuk meg.

Mértük a növényi átlagminták friss és légszáraz tömegét $\left(40-50{ }^{\circ} \mathrm{C}\right.$-on történő szárítást követően), majd a mintegy $300 \mathrm{db}$ átlagmintát finomra daráltuk és cc. $\mathrm{HNO}_{3}+$ cc. $\mathrm{H}_{2} \mathrm{O}_{2}$ roncsolás után 20-24 elemre analizáltuk ICP-technikát alkalmazva. Talajmintavételre 1994-ben került sor. Ekkor parcellánként 20-20 pontminta egyesítésével átlagmintákat képeztünk a szántott rétegből és meghatároztuk az „összes” készletet cc. $\mathrm{HNO}_{3}+\mathrm{cc} . \mathrm{H}_{2} \mathrm{O}_{2}$ roncsolásból, valamint az $\mathrm{NH}_{4}$-acetát + EDTA-oldható tartalmakat LAKANEN és ERVIÖ (1971) szerint.

A spenótlevél karotinoid-tartalmának meghatározására parcellánként szintén 60-60 db levelet gyüjtöttünk. A friss mintákat azonnal a Központi Élelmiszeripari Kutatóintézet Lipidkémiai Laboratóriumába szállítottuk, ahol apróra vágtuk és homogenizáltuk porcelán tégelyben, kvarchomokkal péppé keverve. Az 5 g növényi anyaghoz $50 \mathrm{ml}$ acetont adtunk és 15 perces rázatás, valamint szürés 


\section{1. táblázat}

A spenót kísérletben végzett müveletek és megfigyelések, 1995-1996 (Karbonátos csernozjom talaj, Nagyhörcsök)

\begin{tabular}{|c|c|c|}
\hline $\begin{array}{c}\text { (1) } \\
\text { Müveletek megnevezése }\end{array}$ & $\begin{array}{c}\text { (2) } \\
\text { Időpontja } \\
\text { (év, hónap, nap) } \\
\end{array}$ & $\begin{array}{c}(3) \\
\text { Megjegyzés }\end{array}$ \\
\hline 1. Öszi NPK-mütrágyázás & 1995.11 .14$. & Parcellánként kézzel \\
\hline 2. Egyirányú szántás & 1996. 03. 01. & MTZ-80 + Lajta eke \\
\hline 3. Tavaszi N-mütrágyázás & 1996. 04. 11. & Parcellánként kézzel \\
\hline 4. Kombinátorozás & 1996. 04. 11. & MTZ-50 + kombinátor \\
\hline 5. Vetés szemenként géppel & 1996. 04. 17. & MTZ-50+NIBEX vetőgép \\
\hline 6. Hengerezés & 1996. 04. 17. & MTZ-50+simahenger \\
\hline 7. Kerítés kihelyezése & 1996. 05. 07. & Kísérlet körülkerítve \\
\hline 8. Kísérlet kitűzése kelés után & 1996. 05.07. & Karók lehelyezése parc.-ként \\
\hline 9. Gyomfelvételezés & 1996. 05. 12. & Parcellánként (Radics L.) \\
\hline 10. Bonitálás állományra & 1996. 05. 22. & Parcellánként 1-5 skálán \\
\hline 11. Gyomirtó kapálás & 1996. 05. 24. & Az egész kísérletben \\
\hline 12. Bonitálás elszineződésre & 1996.06.03. & Parcellánként 1-5 skálán \\
\hline 13. Levélmintavétel & 1996.06.03. & Parcellánként 60 db levél \\
\hline 14. Bonitálás állományra & 1996. 07. 23. & Parcellánként 1-5 skálán \\
\hline 15. Betakarítás & 1996. 07. 23. & Parcellánként 8 fm mintakéve \\
\hline 16. Talajmintavétel szintenként & 1996. 08. 12. & Gépi mélyfúrás 1 m-ig \\
\hline 17. Szárvágás, letakarítás & 1996. 08. 21. & Az egész kísérletben \\
\hline 18. Tárcsázás, hengerezés & 1996. 08. 21. & MTZ-50+tárcsa, henger \\
\hline 19. Mintakéve feldolgozása & 1996.09 .17$. & Parcellánként szem, szalma \\
\hline 20. Minták darálása & 1996. 09. 20. & Parcellánként analízisre \\
\hline
\end{tabular}

után történt a pigmentek meghatározása HPLC-technikát alkalmazva. A módszert átfogóan egy korábbi közlemény ismerteti (BIACS \& DAOOD, 1994).

A kísérlet első évében kukoricát, a 2. évben sárgarépát, a 3. évben burgonyát, a 4. évben borsót, az 5. évben céklát termesztettünk. A kísérlet célját, módszerét, a megelőző évek főbb eredményeit korábbi közleményeink taglalják (KÁDÁR et al., 2000, 2001). Megemlítjük, hogy 1996 áprilisában 11, májusában 63, júniusában 41 , júliusában $15 \mathrm{~mm}$ csapadék hullott, mely összességében ugyan jelentősen elmaradt a sokévi átlagtól, mégis kielégítő termést kaptunk. A havi, negyedéves, éves és a tenyészidő alatti csapadékösszegek adatait az 19952000. évekre szintén az előző munkánk közli részletesen (KÁDÁR et al., 2001). 


\section{Kísérleti eredmények}

Mikroelem-terhelés hatása a gyomboritásra és a spenót fejlödésére

A 2. táblázat adatai szerint a spenót gyomfedettségi \%-át május 12-én, a gyomirtó kapálás elött mindössze három elem csökkentette bizonyíthatóan: As, $\mathrm{Cd}$, Se. A gyomfedettséget a Cr-terhelés is mérsékelte, viszont a kadmium toxikus hatása az uralkodó Amaranthus blitoides gyomfajra nem jelentkezett. A spenót közismerten gyorsan fejlödésnek indul és a talajt borítja, így gyomelnyomó képessége jó. Döntően 2-3 amaranthus fajt tudtunk azonosítani a kísérletben.

Június 3-án a spenótlevél szedésre alkalmassá vált, a növények magassága szennyezetlen talajon elérte a $20-25 \mathrm{~cm}-\mathrm{t}$, a friss levéltömeg pedig a 17-19 t/ha mennyiséget. A nagyobb Se-, ill. a maximális Cd-terhelésnél a növényzet gyakorlatilag kipusztult. Július 23 -ára, a száraz meleg időjárás nyomán a spenót

\section{2. táblázat}

Fitotoxicitást okozó kezelések hatása a növényi fedettségre 1996. május 12-én (Karbonátos csernozjom talaj, Nagyhörcsök)

\begin{tabular}{|c|c|c|c|c|c|c|}
\hline \multirow{2}{*}{$\begin{array}{c}(1) \\
\text { Elem }\end{array}$} & \multicolumn{4}{|c|}{ (2) Terhelés 1991 tavaszán, kg/ha } & \multirow{2}{*}{$\begin{array}{c}(3) \\
\mathbf{S z D}_{\mathbf{5} \%} \\
\end{array}$} & \multirow{2}{*}{ Átlag } \\
\hline & $\mathbf{0}$ & 90 & 270 & 810 & & \\
\hline \multicolumn{7}{|c|}{ A. Spenótfedettség \%-a } \\
\hline As & 40 & 50 & 45 & 8 & & 36 \\
\hline $\mathrm{Cd}$ & 40 & 28 & 18 & 8 & 14 & 24 \\
\hline $\mathrm{Cr}$ & 45 & 45 & 52 & 45 & & 47 \\
\hline $\mathrm{Se}$ & 38 & 24 & 3 & 1 & & 16 \\
\hline \multicolumn{7}{|c|}{ B. Gyomfedettség \%- $a$} \\
\hline As & 33 & 38 & 20 & 4 & & 24 \\
\hline $\mathrm{Cd}$ & 28 & 50 & 18 & 22 & 22 & 30 \\
\hline $\mathrm{Cr}$ & 34 & 33 & 21 & 8 & & 24 \\
\hline $\mathrm{Se}$ & 33 & 28 & 16 & 1 & & 20 \\
\hline \multicolumn{7}{|c|}{ C. Összes fedettség } \\
\hline As & 73 & 88 & 65 & 11 & & 59 \\
\hline $\mathrm{Cd}$ & 68 & 78 & 35 & 30 & 30 & 53 \\
\hline $\mathrm{Cr}$ & 79 & 78 & 74 & 54 & & 72 \\
\hline $\mathrm{Se}$ & 71 & 52 & 18 & 1 & & 36 \\
\hline \multicolumn{7}{|c|}{ D. Amaranthus blitoides fedettség $\%$-a } \\
\hline As & 32 & 38 & 20 & 1 & & 23 \\
\hline $\mathrm{Cd}$ & 28 & 50 & 18 & 22 & 23 & 29 \\
\hline $\mathrm{Cr}$ & 23 & 32 & 20 & 8 & & 21 \\
\hline $\mathrm{Se}$ & 32 & 28 & 16 & 1 & & 19 \\
\hline
\end{tabular}


gyorsan felmagzott és magtermését beérlelte. A légszáraz szártömeg 2,5 t/ha, míg a mag 3,0 t/ha mennyiséget adott a kontrolltalajon. Megemlítjük, hogy a június 3-án vett friss levéltermés mindössze 10-12\% légszáraz anyagot tartalmazott, így az átlagos légszárazanyag-hozama $2-2$ t/ha körülinek adódott a kontrolltalajon. A föld feletti tömeg 80-85\%-át ekkor a levéltermés adta (3. táblázat).

\section{3. táblázat}

Terméscsökkenést okozó toxikus elemek hatása a spenótra, 1996 (Karbonátos csernozjom talaj, Nagyhörcsök)

\begin{tabular}{|c|c|c|c|c|c|c|}
\hline \multirow{2}{*}{$\begin{array}{c}(1) \\
\text { Elem }\end{array}$} & \multicolumn{4}{|c|}{ (2) Terhelés 1991 tavaszán, kg/ha } & \multirow{2}{*}{$\begin{array}{c}(3) \\
\mathbf{S z D}_{\mathbf{5} \%}\end{array}$} & \multirow{2}{*}{$\begin{array}{c}\text { (4) } \\
\text { Átlag }\end{array}$} \\
\hline & $\mathbf{0}$ & 90 & 270 & 810 & & \\
\hline \multicolumn{7}{|c|}{ A. Átlagos növénymagasság jún. 3-án, cm } \\
\hline As & 25 & 20 & 23 & 10 & & 20 \\
\hline $\mathrm{Cd}$ & 20 & 13 & 10 & 10 & 13 & 13 \\
\hline $\mathrm{Cr}$ & 21 & 23 & 28 & 28 & & 25 \\
\hline $\mathrm{Se}$ & 23 & 15 & 0 & 0 & & 10 \\
\hline \multicolumn{7}{|c|}{ B. Bonitálás állományra júl. 23-án* } \\
\hline As & 4,5 & 5,0 & 4,5 & 2,0 & & 4,0 \\
\hline $\mathrm{Cd}$ & 3,5 & 3,5 & 2,0 & 0,0 & 1,2 & 2,0 \\
\hline $\mathrm{Cr}$ & 5,0 & 5,0 & 5,0 & 5,0 & & 5,0 \\
\hline $\mathrm{Se}$ & 4,5 & 1,5 & 0,0 & 0,0 & & 1,5 \\
\hline \multicolumn{7}{|c|}{ C. Zöld levéltermés jún. 3-án, t/ha** } \\
\hline As & 18 & 15 & 13 & 10 & & 14 \\
\hline $\mathrm{Cd}$ & 17 & 11 & 10 & 4 & 7 & 11 \\
\hline $\mathrm{Cr}$ & 18 & 18 & 23 & 24 & & 21 \\
\hline $\mathrm{Se}$ & 19 & 16 & 0 & 0 & & 9 \\
\hline \multicolumn{7}{|c|}{ D. Légszáraz szártermés júl. 23-án, t/ha } \\
\hline As & 2,5 & 1,7 & 2,4 & 2,2 & & 2,2 \\
\hline $\mathrm{Cd}$ & 2,5 & 1,8 & 1,6 & 0,0 & 1,0 & 1,5 \\
\hline $\mathrm{Cr}$ & 2,6 & 2,8 & 3,0 & 2,3 & & 2,6 \\
\hline $\mathrm{Se}$ & 2,4 & 1,8 & 0,0 & 0,0 & & 1,0 \\
\hline \multicolumn{7}{|c|}{ E. Légszáraz magtermés júl. 23-án, t/ha } \\
\hline As & 2,8 & 2,1 & 2,9 & 1,6 & & 2,3 \\
\hline $\mathrm{Cd}$ & 2,9 & 2,2 & 2,0 & 0,0 & 1,0 & 1,7 \\
\hline $\mathrm{Cr}$ & 3,0 & 3,4 & 3,3 & 2,5 & & 3,0 \\
\hline $\mathrm{Se}$ & 3,0 & 1,8 & 0,0 & 0,0 & & 1,2 \\
\hline
\end{tabular}

Megjegyzés: * Bonitálás: $0=$ növényzet kipusztult, 1 = gyenge, 5 = erős állomány ** A föld feletti tömeg 80-85 \%-át a levéltermés adja. Légszáraz anyag $12 \%$, az átlagos légszáraz anyag hozama szennyezetlen talajon 2,2 t/ha 
Mikroelem-terhelés hatása a spenót ásványi összetételére

A kezelések hatását a spenót ásványi összetételére a 4. táblázatban tanulmányozhatjuk. Amint a táblázatban látható, az As-beépülés mindössze 3-4 mg/ $/ \mathrm{kg}$ értéket ért el a vegetatív szervekben, ill. $1 \mathrm{mg} / \mathrm{kg}$ alatt maradt a magban még az extrém As-terhelésủ talajon is. A 8/1985. (X.21.) EüM rendelet szárított zöldségre maximálisan $4 \mathrm{mg} / \mathrm{kg}$ As-, $2 \mathrm{mg} / \mathrm{kg} \mathrm{Pb}$-, $0,3 \mathrm{mg} / \mathrm{kg}$ Cd- és $0,05 \mathrm{mg} / \mathrm{kg} \mathrm{Hg}$ koncentrációt engedélyez. Egyéb elemekre nem ad meg határértékeket. Az arzénnel szennyezett talajon tehát a spenót levele fogyasztásra alkalmas maradt.

A bárium mérsékelten, 3-5-szörösére dúsult a maximális Ba-terhelés nyomán. A kadmium viszont - az irodalmi adatokkal összhangban - extrém akkumulációt mutatott a levélben a kontrollhoz képest, ahol 144-szeresére emelkedett. A $0,3 \mathrm{mg} / \mathrm{kg}$ határértéket már a kontroll növényei is meghaladták, feltehetően a szennyezett parcellákról történt légköri áthordás (rárakódó por) következtében. A levélhez viszonyítva (100\%) a szár maximálisan mintegy $20 \%$, míg a mag $10 \%$ akkumulációt jelzett. A króm közepes, a magban maximálisan 12-, a vegetatív részekben 23-27-szeres koncentrációnövekedést produkált.

A réz mozgása erősen gátolt, koncentrációja átlagosan 2-3-szorosára nőtt a föld feletti részekben. Hg-dúsulást csak a vegetatív részekben lehetett kimutatni és csak extrém terhelésnél. A higany föként a fiatal levélben halmozódott fel $3,1-9,6 \mathrm{mg} / \mathrm{kg}$ mennyiségben. A spenót levele tehát a $270 \mathrm{ill} .810 \mathrm{~kg} /$ ha kezelésü parcellákon már emberi fogyasztásra alkalmatlan terméket eredményezett, kifejezetten szennyezetté vált (4. táblázat).

A molibdén és szelén már a $90 \mathrm{~kg} /$ ha terhelésnél hiperakkumulációt mutatott, három nagyságrendbeli dúsulással. $\mathrm{E}$ két elem tömegárammal akadálytalanul bejuthat a föld feletti szervekbe, föként a levélbe. A molibdén túlsúlya nem okozott fitotoxicitást. Az $5 \mathrm{mg} / \mathrm{kg}$ feletti Mo-koncentrációt azonban már károsnak tekintjük, mert $\mathrm{Cu}$-hiányt indukálhat az emberi vagy állati szervezetben, míg az extrém Mo-túlsúly toxikózishoz vezethet. Az 1-2 mg/kg feletti Se-tartalom szintén károsnak minősül. Hasonló talajon tehát már a mérsékeltebb Mo-, ill. Se-szennyezés is fogyasztásra alkalmatlan termést eredményezhet (4. táblázat).

A nikkel és az ólom gyengén dúsult, mindössze néhány $\mathrm{mg} / \mathrm{kg}$ maximális koncentrációt mutatott a szárban és a levélben. A magban az ólom a $0,1 \mathrm{mg} / \mathrm{kg}$ kimutathatósági határ alatt maradt. Mivel a szárított zöldségre $2 \mathrm{mg} \mathrm{Pb} / \mathrm{kg}$ a megengedett felső határ, a 270 és $810 \mathrm{~kg}$ /ha kezelésekben termett spenótlevél fogyasztásra alkalmatlannak minősül. A kevésbé veszélyes jelleg miatt a szabványok nem közölnek limit koncentrációkat a $\mathrm{Ni}, \mathrm{Sr}, \mathrm{Zn}$ elemekre. A levélben a stroncium 5-szörösére, a cink viszont 17-szeresére emelkedett a maximális terhelés nyomán. Ilyen mérvü dúsulás, mely a kiegyensúlyozott összetételt veszélyezteti, élettanilag szintén elfogadhatatlannak tekinthető (4. táblázat). 
4. táblázat

Terhelés hatása a légszáraz spenót elemtartalmára 1996-ban

(Karbonátos csernozjom talaj, Nagyhörcsök)

\begin{tabular}{|c|c|c|c|c|c|c|}
\hline \multirow{2}{*}{$\begin{array}{l}\text { (1) } \\
\text { Növényi } \\
\text { rész }\end{array}$} & \multicolumn{4}{|c|}{$\begin{array}{c}(2) \\
\text { Terhelés } 1991 \text { tavaszán, } \mathbf{k g} / \mathbf{h a}\end{array}$} & \multirow{2}{*}{$\begin{array}{c}(3) \\
\mathbf{S z D}_{\mathbf{5} \%}\end{array}$} & \multirow[t]{2}{*}{ Átlag } \\
\hline & 0 & 90 & 270 & 810 & & \\
\hline \multicolumn{7}{|c|}{ A. As-terhelés hatására, mg As/kg } \\
\hline a) Levél ${ }^{1}$ & 0,0 & 0,0 & 0,9 & 3,9 & 0,2 & 1,2 \\
\hline b) Szár ${ }^{2}$ & 0,0 & 0,4 & 1,7 & 3,6 & 0,2 & 1,4 \\
\hline c) $\mathrm{Mag}^{2}$ & 0,0 & 0,1 & 0,3 & 0,6 & 0,1 & 0,3 \\
\hline \multicolumn{7}{|c|}{ B. Ba-terhelés hatására, mg Ba/kg } \\
\hline a) Levél ${ }^{1}$ & 7,1 & 8,2 & 13,8 & 37,2 & 8,1 & 16,1 \\
\hline b) Szár ${ }^{2}$ & 7,0 & 9,9 & 14,0 & 20,8 & 3,0 & 12,9 \\
\hline c) $\mathrm{Mag}^{2}$ & 1,8 & 2,0 & 3,0 & 5,4 & 0,9 & 3,0 \\
\hline \multicolumn{7}{|c|}{ C. Cd-terhelés hatására, $\mathrm{mg} \mathrm{Cd} / \mathrm{kg}$} \\
\hline a) Levél ${ }^{1}$ & 1.0 & 82 & 106 & 144 & 8 & 83 \\
\hline b) Szár ${ }^{2}$ & 0.3 & 17 & 23 & - & 4 & 13 \\
\hline c) $\mathrm{Mag}^{2}$ & 0.2 & 9 & 10 & - & 1 & 6 \\
\hline \multicolumn{7}{|c|}{ D. Cr-terhelés hatására, $\mathrm{mg} \mathrm{Cr} / \mathrm{kg}$} \\
\hline a) Levél ${ }^{1}$ & 0,7 & 2,9 & 7,2 & 16,2 & 1,7 & 6,8 \\
\hline b) Szár ${ }^{2}$ & 0,3 & 1,7 & 4,5 & 8,2 & 1,0 & 3,7 \\
\hline c) $\mathrm{Mag}^{2}$ & 0,3 & 0,7 & 1,8 & 3,6 & 0,3 & 1,6 \\
\hline \multicolumn{7}{|c|}{ E. Cu-terhelés hatására, $m g \mathrm{Cu} / \mathrm{kg}$} \\
\hline a) Levél ${ }^{1}$ & 6,3 & 8,0 & 10,8 & 18,5 & 2,7 & 10,9 \\
\hline b) Szár ${ }^{2}$ & 3,2 & 3,4 & 4,5 & 5,1 & 1,0 & 4,0 \\
\hline c) $\mathrm{Mag}^{2}$ & 3,5 & 5,5 & 7,3 & 8,2 & 0,9 & 6,1 \\
\hline \multicolumn{7}{|c|}{ F. Hg-terhelés hatására, $m g \mathrm{Hg} / \mathrm{kg}$} \\
\hline a) Levél ${ }^{1}$ & 0,0 & 0,0 & 3,1 & 9,6 & 0,4 & 3,2 \\
\hline b) Szár ${ }^{2}$ & 0,0 & 0,0 & 0,1 & 0,8 & 0,2 & 0,2 \\
\hline c) $\mathrm{Mag}^{2}$ & 0,0 & 0,0 & 0,0 & 0,0 & 0,0 & 0,0 \\
\hline \multicolumn{7}{|c|}{ G. Mo-terhelés hatására, mg Mo/kg } \\
\hline a) Levél ${ }^{1}$ & 0,0 & 223 & 412 & 670 & 97 & 326 \\
\hline b) Szár ${ }^{2}$ & 0,1 & 31 & 97 & 132 & 9 & 65 \\
\hline c) $\mathrm{Mag}^{2}$ & 0,0 & 13 & 42 & 80 & 6 & 34 \\
\hline \multicolumn{7}{|c|}{ H. Ni-terhelés hatására, mg Ni/kg } \\
\hline a) Levél ${ }^{1}$ & 0,5 & 1,2 & 2,3 & 4,1 & 0,4 & 2,0 \\
\hline b) Szár ${ }^{2}$ & 0,7 & 0,7 & 1,7 & 2,9 & 0,5 & 1,5 \\
\hline c) $\mathrm{Mag}^{2}$ & 0,4 & 0,7 & 1,4 & 2,4 & 0,3 & 1,2 \\
\hline
\end{tabular}


4. táblázat folytatása

\begin{tabular}{|c|c|c|c|c|c|c|}
\hline \multirow{2}{*}{$\begin{array}{c}\text { (1) } \\
\text { Növényi } \\
\text { rész }\end{array}$} & \multicolumn{4}{|c|}{$\begin{array}{c}\text { (2) } \\
\text { Terhelés } 1991 \text { tavaszán, kg/ha }\end{array}$} & \multirow{2}{*}{$\begin{array}{c}(3) \\
\mathbf{S z D}_{\mathbf{5} \%}\end{array}$} & \multirow{2}{*}{ Átlag } \\
\hline & $\mathbf{0}$ & 90 & 270 & 810 & & \\
\hline \multicolumn{7}{|c|}{ I. Pb-terhelés hatására, $\mathrm{mg} \mathrm{Pb/kg}$} \\
\hline a) Levél ${ }^{1}$ & 0,5 & 0,6 & 1,3 & 1,8 & 0,9 & 1,0 \\
\hline b) Szár ${ }^{2}$ & 0,2 & 0,6 & 1,2 & 2,4 & 0,3 & 1,1 \\
\hline c) $\mathrm{Mag}^{2}$ & 0,0 & 0,0 & 0,0 & 0,0 & 0,0 & 0,0 \\
\hline \multicolumn{7}{|c|}{ J. Se-terhelés hatására, mg Se/kg } \\
\hline a) Levél ${ }^{1}$ & 0,2 & 765 & - & - & 96 & 383 \\
\hline b) Szár ${ }^{2}$ & 0,2 & 70 & - & - & 12 & 35 \\
\hline c) $\mathrm{Mag}^{2}$ & 0,3 & 105 & - & - & 16 & 53 \\
\hline \multicolumn{7}{|c|}{ K. Sr-terhelés hatására, $\mathrm{mg} \mathrm{Sr} / \mathrm{kg}$} \\
\hline a) Levél ${ }^{1}$ & 99 & 164 & 268 & 518 & 35 & 262 \\
\hline b) Szár ${ }^{2}$ & 71 & 111 & 140 & 272 & 30 & 149 \\
\hline c) $\mathrm{Mag}^{2}$ & 26 & 32 & 37 & 83 & 9 & 44 \\
\hline \multicolumn{7}{|c|}{ L. Zn-terhelés hatására, $\mathrm{mg} \mathrm{Zn} / \mathrm{kg}$} \\
\hline a) Levél ${ }^{1}$ & 17 & 163 & 242 & 289 & 26 & 178 \\
\hline b) Szár ${ }^{2}$ & 5 & 23 & 30 & 42 & 3 & 25 \\
\hline c) $\mathrm{Mag}^{2}$ & 18 & 49 & 53 & 56 & 7 & 44 \\
\hline
\end{tabular}

Megjegyzés: ${ }^{1}$ : jún. 3-án, ${ }^{2}$ : júl. 23-án betakarításkor; As-, Hg-, Mo- és Pb-koncentráció $0,1 \mathrm{mg} / \mathrm{kg}$ alatt szennyezetlen talajon

Mikroelem-terhelés hatása a spenót levelének klorofill- és karotinoid-tartalmára

A friss spenótlevél klorofill-A- és klorofill-A'-készlete tendenciájában igazolhatóan emelkedett a Cr- és Se-kezelésekben. Az As- és Cd-kezelésekben érdemi változást nem tapasztaltunk. A klorofill-B mennyisége viszont csökkent a maximális As-kezelésben, ill. megkétszereződött a Se-terhelés nyomán. Figyelemre méltó változás történt a krómmal szennyezett talajon, ahol szemmel láthatóan a klorofill-B frakció klorofill-B' módosulattá alakult át és mennyisége egy nagyságrenddel megemelkedett. A Se-terhelés a klorofill-B' frakciónak szintén nagyságrendi növelését eredményezte (5. táblázat).

A karotinoidok - ezek a zsírban oldódó biológiailag aktív pigmentek - nemcsak a fotoszintézist segítik elő a fény abszorpciójával és a fényenergia szállításával, hanem a klorofill oxidatív károsodása ellen is védelmet nyújtanak. Együtt képződnek a klorofillal és - mint antioxidánsok $\left(\mathrm{H}^{+}\right.$donorok $)$- a telítetlen zsírsavakra is hatnak. A béta-karotin szimmetrikus felépítésü, optikailag aktív. 


\section{5. táblázat}

Fitotoxikus kezelések hatása a friss spenótlevél klorofill-tartalmára 1996. jún. 3-án (Karbonátos csernozjom talaj, Nagyhörcsök)

\begin{tabular}{|c|c|c|c|c|c|c|}
\hline \multirow{2}{*}{$\begin{array}{c}(1) \\
\text { Elem }\end{array}$} & \multicolumn{4}{|c|}{ (2) Terhelés 1991 tavaszán, $\mathbf{k g} / \mathbf{h a}$} & \multirow{2}{*}{$\begin{array}{c}(3) \\
\mathrm{SzD}_{\mathbf{5}}\end{array}$} & \multirow{2}{*}{$\begin{array}{l}\text { (4) } \\
\text { Átlag }\end{array}$} \\
\hline & $\mathbf{0}$ & 90 & 270 & 810 & & \\
\hline \multicolumn{7}{|c|}{ Klorofill- $A, \mathrm{mg} / \mathrm{kg}$} \\
\hline As & 92 & 96 & 77 & 65 & & 83 \\
\hline $\mathrm{Cd}$ & 89 & 95 & 84 & 80 & 44 & 87 \\
\hline $\mathrm{Cr}$ & 89 & 112 & 114 & 128 & & 111 \\
\hline $\mathrm{Se}$ & 90 & 154 & - & - & & 122 \\
\hline \multicolumn{7}{|c|}{ Klorofill-A', $\mathrm{mg} / \mathrm{kg}$} \\
\hline As & 5,9 & 9,3 & 5,4 & 4,9 & & 6,4 \\
\hline $\mathrm{Cd}$ & 5,5 & 8,1 & 5,6 & 5,8 & 5,1 & 6,2 \\
\hline $\mathrm{Cr}$ & 5,5 & 11,7 & 12,3 & 11,7 & & 10,3 \\
\hline $\mathrm{Se}$ & 6,7 & 20,8 & - & - & & 13,8 \\
\hline \multicolumn{7}{|c|}{ Klorofill-B, $\mathrm{mg} / \mathrm{kg}$} \\
\hline As & 25 & 24 & 24 & 13 & & 22 \\
\hline $\mathrm{Cd}$ & 21 & 32 & 23 & 18 & 8 & 24 \\
\hline $\mathrm{Cr}$ & 23 & 20 & 3 & 0.0 & & 12 \\
\hline $\mathrm{Se}$ & 26 & 55 & - & - & & 40 \\
\hline \multicolumn{7}{|c|}{ Klorofill-B', $\mathrm{mg} / \mathrm{kg}$} \\
\hline As & 2,6 & 1,4 & 2,0 & 0,0 & & 1,5 \\
\hline $\mathrm{Cd}$ & 2,9 & 5,1 & 1,0 & 0,2 & 3 & 2,3 \\
\hline $\mathrm{Cr}$ & 2,7 & 6,4 & 25,7 & 23,9 & & 14,6 \\
\hline $\mathrm{Se}$ & 2,6 & 20,0 & - & - & & 11,3 \\
\hline
\end{tabular}

Megjegyzés: - = A növényzet kipusztult

Széthasítva két A-vitamint képezhet. Amint a 6. táblázat adataiból kitünik, a spenót levele elsősorban luteinban és $\beta$-tokoferolban gazdag, $\beta$-karotinban viszont szegény.

A Se-szennyezés nyomán látványosan és igazolhatóan nőtt a lutein koncentrációja a friss spenót levelében. A $\beta$-tokoferol tartalmát az arzén, króm és szelén egyaránt mérsékelte. A $\beta$-karotin mennyiségét drasztikusan emelte a szelén, míg a króm mérsékelten emelte.

Összefoglalóan megállapítható, hogy a talajszennyezés, a mikroelemek túlsúlya nemcsak a termés mennyiségét és ásványi összetételét változtathatja meg, hanem tükröződhet a termék egyéb minőségi jellemzőin, a klorofill és egyéb pigmentek mennyiségén, ill. egymáshoz viszonyított arányán. 


\section{6. táblázat}

Fitotoxikus kezelések hatása a friss spenótlevél lutein-, $\beta$-karotin- és $\beta$-tokoferoltartalmára 1996. jún. 3-án

(Karbonátos csernozjom talaj, Nagyhörcsök)

\begin{tabular}{|c|c|c|c|c|c|c|}
\hline \multirow{2}{*}{$\begin{array}{c}(1) \\
\text { Elem }\end{array}$} & \multicolumn{4}{|c|}{ (2) Terhelés 1991 tavaszán, kg/ha } & \multirow{2}{*}{$\begin{array}{c}(3) \\
\mathbf{S z D}_{\mathbf{5} \%}\end{array}$} & \multirow{2}{*}{$\begin{array}{c}\text { (4) } \\
\text { Átlag }\end{array}$} \\
\hline & $\mathbf{0}$ & 90 & 270 & 810 & & \\
\hline \multicolumn{7}{|c|}{ Lutein, $\mathrm{mg} / \mathrm{kg}$} \\
\hline As & 73 & 83 & 72 & 48 & & 69 \\
\hline $\mathrm{Cd}$ & 79 & 102 & 76 & 77 & 28 & 84 \\
\hline $\mathrm{Cr}$ & 70 & 79 & 88 & 60 & & 74 \\
\hline $\mathrm{Se}$ & 76 & 166 & - & - & & 121 \\
\hline \multicolumn{7}{|c|}{$\beta$-tokoferol, $\mathrm{mg} / \mathrm{kg}$} \\
\hline As & 24 & 26 & 23 & 14 & & 22 \\
\hline $\mathrm{Cd}$ & 22 & 24 & 24 & 26 & 8 & 24 \\
\hline $\mathrm{Cr}$ & 25 & 25 & 20 & 14 & & 21 \\
\hline $\mathrm{Se}$ & 23 & 13 & - & - & & 18 \\
\hline \multicolumn{7}{|c|}{$\beta$-karotin, $\mathrm{mg} / \mathrm{kg}$} \\
\hline As & 5,3 & 8,5 & 2,6 & 2,7 & & 4,8 \\
\hline $\mathrm{Cd}$ & 4,1 & 8,0 & 1,5 & 1,9 & 4,9 & 3,8 \\
\hline $\mathrm{Cr}$ & 3,1 & 7,0 & 11,1 & 9,0 & & 7,5 \\
\hline $\mathrm{Se}$ & 5,5 & 31,4 & - & - & & 18,4 \\
\hline
\end{tabular}

Megjegyzés: - = A növényzet kipusztult

\section{A spenót átlagos összetétele és elemfelvétele szennyezetlen talajon}

A 7. táblázat eredményei szerint a június 3-án szedett levelek alacsonyabb N-, P-, Zn-, Cu- és Mo-, valamint emelkedett Ca- és Mn-tartalommal rendelkeztek, mint a BERGMANN (1988) által közölt irodalmi optimum. A $\mathrm{NO}_{3}$-N-koncentráció is mérsékelt maradt. Amennyiben a szár és a mag összetételét vizsgáljuk megállapítható, hogy a mag $\mathrm{N}, \mathrm{P}$ és Zn elemekben dúsabb. A többi vizsgált makro- és mikroelem döntően a szártermésben akkumulálódott. Az As, Hg, Mo elemek koncentrációja $0,1 \mathrm{mg} / \mathrm{kg}$, ill. méréshatár alatt maradt.

A 17-19 t/ha friss levéltermés, mely 2,2 t/ha légszárazanyag-hozamot jelentett, $84 \mathrm{~kg} \mathrm{~K}$-, $58 \mathrm{~kg} \mathrm{~N}-, 51 \mathrm{~kg} \mathrm{Ca-}, 12 \mathrm{~kg}$ Mg- és 7-9 kg S- ill. P-készlettel rendelkezett. A $10 \mathrm{t}$ friss levéltermés fajlagos elemigénye $56 \mathrm{~kg} \mathrm{~K} \mathrm{~K}_{2} \mathrm{O}, 32 \mathrm{~kg} \mathrm{~N}$ és $9 \mathrm{~kg} \mathrm{P}_{2} \mathrm{O}_{5}$ mennyiséggel jellemezhető ezen a talajon. A TERBE (1994) által közölt fajlagos értékek jó egyezést mutatnak a $\mathrm{N}$ és $\mathrm{K}_{2} \mathrm{O}$ esetén, míg a $18 \mathrm{~kg}$ $\mathrm{P}_{2} \mathrm{O}_{5}$ kétszeres túlsúlyt mutat. Szaktanácsadásban a fajlagos tartalmakat szorozzuk a tervezett terméssel, hogy a tápelemigényt becsülhessük. Mindez akkor helyénvaló, ha a zöld levéltermést betakarítva a melléktermékeket leszántjuk (8. táblázat). 


\section{7. táblázat}

A légszáraz spenót átlagos összetétele szennyezetlen talajon 1996-ban (Karbonátos csernozjom talaj, Nagyhörcsök)

\begin{tabular}{|l|c|c|c|c|}
\hline \multirow{2}{*}{$\begin{array}{c}\text { Elem } \\
\text { jele }\end{array}$} & $\begin{array}{c}\text { Mérték- } \\
\text { egység }\end{array}$ & $\begin{array}{c}\text { Levél } \\
\text { jún. 3-án }\end{array}$ & $\begin{array}{c}(4) \\
\text { Szár }\end{array}$ & \begin{tabular}{c} 
Mag \\
\cline { 3 - 5 }
\end{tabular} \\
\cline { 4 - 5 } $\mathrm{K}$ & $\%$ & 4,67 & \multicolumn{2}{|c|}{ júl. 23-án } \\
$\mathrm{N}$ & $\%$ & 3,20 & 2,07 & 1,00 \\
$\mathrm{Ca}$ & $\%$ & 2,82 & 1,10 & 2,77 \\
$\mathrm{Mg}$ & $\%$ & 0,64 & 1,61 & 0,72 \\
$\mathrm{~S}$ & $\%$ & 0,52 & 0,71 & 0,32 \\
$\mathrm{P}$ & $\%$ & 0,41 & 0,28 & 0,21 \\
$\mathrm{Na}$ & $\mathrm{mg} / \mathrm{kg}$ & 953 & 0,11 & 0,46 \\
$\mathrm{NO}-\mathrm{N}$ & $\mathrm{mg} / \mathrm{kg}$ & 636 & 1504 & 186 \\
$\mathrm{Fe}$ & $\mathrm{mg} / \mathrm{kg}$ & 395 & 272 & 288 \\
$\mathrm{Al}$ & $\mathrm{mg} / \mathrm{kg}$ & 364 & 249 & 70 \\
$\mathrm{Mn}$ & $\mathrm{mg} / \mathrm{kg}$ & 254 & 200 & 14 \\
$\mathrm{Sr}$ & $\mathrm{mg} / \mathrm{kg}$ & 99 & 67 & 75 \\
$\mathrm{~B}$ & $\mathrm{mg} / \mathrm{kg}$ & 53 & 71 & 26 \\
$\mathrm{Zn}$ & $\mathrm{mg} / \mathrm{kg}$ & 17 & 22 & 12 \\
$\mathrm{Ba}$ & $\mathrm{mg} / \mathrm{kg}$ & 7 & 5 & 18 \\
$\mathrm{Cu}$ & $\mathrm{mg} / \mathrm{kg}$ & 6 & 7 & 2 \\
$\mathrm{Cd}$ & $\mathrm{mg} / \mathrm{kg}$ & 1,0 & 3 & 4 \\
$\mathrm{Cr}$ & $\mathrm{mg} / \mathrm{kg}$ & 0,7 & 0,3 & 0,2 \\
$\mathrm{Ni}$ & $\mathrm{mg} / \mathrm{kg}$ & 0,5 & 0,3 & 0,3 \\
$\mathrm{~Pb}$ & $\mathrm{mg} / \mathrm{kg}$ & 0,5 & 0,7 & 0,4 \\
$\mathrm{Se}$ & $\mathrm{mg} / \mathrm{kg}$ & 0,1 & 0,2 & 0,0 \\
$\mathrm{Co}$ & $\mathrm{mg} / \mathrm{kg}$ & 0,1 & 0,2 & 0,2 \\
\hline
\end{tabular}

Megjegyzés: As, Hg, Mo méréshatár alatt. Levél optimumok BERGMANN (1988) szerint: $\mathrm{K} 3,5-5,3 \%$, N 3,5-5,0 \%, Ca 0,6-1,2 \%, Mg 0,4-0,8 \%, P 0,4-0,6 \%, Mn 40-100 $\mathrm{mg} / \mathrm{kg}, \mathrm{B} 40-80 \mathrm{mg} / \mathrm{kg}, \mathrm{Zn} 20-70 \mathrm{mg} / \mathrm{kg}, \mathrm{Cu} 7-15 \mathrm{mg} / \mathrm{kg}$, Mo 0,3-1,0 mg/kg

A 2,5 t/ha szár, ill, 3,0 t/ha mag termésének elemkészletét összevetve látható, hogy a magterméssel föként a nitrogén, foszfor, mangán, cink, réz és szelén nagyobb része kerül el a tábláról, Kísérletünkben az összesen 7,7 t/ha föld feletti légszáraz tömeg mintegy $170 \mathrm{~kg} \mathrm{~N}$ és $\mathrm{K}, 113 \mathrm{~kg} \mathrm{Ca}, 40 \mathrm{~kg} \mathrm{Mg}$, ill, 22-24 kg S és P elemet akkumulált. A mikroelemek közül a Fe, Al és Mn mennyisége is a $0,8-1,5 \mathrm{~kg}$ között ingadozott. A spenót tehát jelentős szárazanyag-felhalmozásra és elemforgalomra képes növény. Kérdés mennyiben játszhat szerepet a mérsékeltebben szennyezett talajok tisztításában, a fitoremediációban (8. táblázat). 


\section{8. táblázat}

A spenót föld feletti légszáraz termésének elemfelvétele szennyezetlen talajon 1996-ban (Karbonátos csernozjom talaj, Nagyhörcsök)

\begin{tabular}{|l|c|c|c|c|c|}
\hline $\begin{array}{c}\text { Elem } \\
\text { jele }\end{array}$ & $\begin{array}{c}\text { Mérték- } \\
\text { egység }\end{array}$ & $\begin{array}{c}(3) \\
\text { Levélben } \\
\mathbf{2 , 2} \text { t/ha }\end{array}$ & $\begin{array}{c}(4) \\
\text { Szárban } \\
\mathbf{2 , 5} \text { t/ha }\end{array}$ & $\begin{array}{c}(5) \\
\text { Magban } \\
\mathbf{3 , 0} \text { t/ha }\end{array}$ & $\begin{array}{c}\text { Összesen } \\
\mathbf{7 , 7} \text { t/ha }\end{array}$ \\
\hline $\mathrm{K}$ & $\mathrm{kg} / \mathrm{ha}$ & 84 & 52 & 30 & 166 \\
$\mathrm{~N}$ & $\mathrm{~kg} / \mathrm{ha}$ & 58 & 28 & 83 & 169 \\
$\mathrm{Ca}$ & $\mathrm{kg} / \mathrm{ha}$ & 51 & 40 & 22 & 113 \\
$\mathrm{Mg}$ & $\mathrm{kg} / \mathrm{ha}$ & 12 & 18 & 10 & 40 \\
$\mathrm{~S}$ & $\mathrm{~kg} / \mathrm{ha}$ & 9 & 7 & 6 & 22 \\
$\mathrm{P}$ & $\mathrm{kg} / \mathrm{ha}$ & 7 & 3 & 14 & 24 \\
$\mathrm{Na}$ & $\mathrm{kg} / \mathrm{ha}$ & 2 & 4 & 1 & 7 \\
$\mathrm{NO}{ }_{3}-\mathrm{N}$ & $\mathrm{g} / \mathrm{ha}$ & 1145 & 680 & 864 & 2689 \\
$\mathrm{Fe}$ & $\mathrm{g} / \mathrm{ha}$ & 711 & 622 & 210 & 1543 \\
$\mathrm{Al}$ & $\mathrm{g} / \mathrm{ha}$ & 655 & 500 & 42 & 1197 \\
$\mathrm{Mn}$ & $\mathrm{g} / \mathrm{ha}$ & 457 & 168 & 225 & 850 \\
$\mathrm{Sr}$ & $\mathrm{g} / \mathrm{ha}$ & 178 & 178 & 78 & 434 \\
$\mathrm{~B}$ & $\mathrm{~g} / \mathrm{ha}$ & 95 & 55 & 36 & 186 \\
$\mathrm{Zn}$ & $\mathrm{g} / \mathrm{ha}$ & 31 & 12 & 54 & 97 \\
$\mathrm{Ba}$ & $\mathrm{g} / \mathrm{ha}$ & 13 & 18 & 6 & 37 \\
$\mathrm{Cu}$ & $\mathrm{g} / \mathrm{ha}$ & 11 & 8 & 12 & 31 \\
$\mathrm{Cd}$ & $\mathrm{g} / \mathrm{ha}$ & 1,8 & 0,8 & 0,6 & 3,2 \\
$\mathrm{Cr}$ & $\mathrm{g} / \mathrm{ha}$ & 1,3 & 0,8 & 0,9 & 3,0 \\
$\mathrm{Ni}$ & $\mathrm{g} / \mathrm{ha}$ & 0,9 & 1,8 & 1,2 & 3,9 \\
$\mathrm{~Pb}$ & $\mathrm{~g} / \mathrm{ha}$ & 0,9 & 0,5 & 0,0 & 1,4 \\
$\mathrm{Se}$ & $\mathrm{g} / \mathrm{ha}$ & 0,4 & 0,5 & 0,9 & 1,8 \\
$\mathrm{Co}$ & $\mathrm{g} / \mathrm{ha}$ & 0,2 & 0,5 & 0,6 & 1,3 \\
\hline
\end{tabular}

Megjegyzés: Az As, $\mathrm{Hg}$, Mo méréshatár alatt maradt. A $10 \mathrm{t}$ friss levéltermés elemigénye: $47 \mathrm{~kg} \mathrm{~K}\left(56 \mathrm{~kg} \mathrm{~K}_{2} \mathrm{O}\right), 32 \mathrm{~kg} \mathrm{~N}, 28 \mathrm{~kg} \mathrm{Ca}, 7 \mathrm{~kg} \mathrm{Mg}, 5 \mathrm{~kg} \mathrm{~S}, 4 \mathrm{~kg} \mathrm{P}\left(9 \mathrm{~kg} \mathrm{P}{ }_{2} \mathrm{O}_{5}\right)$

\section{A spenót maximális mikroelem-felvétele szennyezett talajon}

A szennyezett talajon fejlődött spenót maximális mikroelem-felvételéről a 9. táblázat adatai nyújtanak áttekintést. A táblázatban megfigyelhető, hogy - az arzén és ólom kivételével - a legnagyobb elemfelvételre a levéltermés képes. A szár és a mag együtt sem éri el a levéltömegben foglalt elemek mennyiségét. Az elemeket a növekvő felvételük szerint rendeztük. Az As-, Pb-, Ni- és Hg-felvétel elhanyagolható, az összes (levél+szár+mag) felvett mennyiség mindössze 12-33 g/ha között ingadozott. 


\section{9. táblázat}

A spenót maximális mikroelem-felvétele szennyezett talajon (g/ha)

(Karbonátos csernozjom talaj, Nagyhörcsök)

\begin{tabular}{|c|c|c|c|c|c|}
\hline \multirow{2}{*}{$\begin{array}{c}(1) \\
\text { Elem } \\
\text { jele }\end{array}$} & \multirow{2}{*}{$\begin{array}{c}\text { (2) } \\
\text { Levélben } \\
\text { jún. 3-án }\end{array}$} & $\begin{array}{c}(3) \\
\text { Szárban } \\
\end{array}$ & $\begin{array}{c}(4) \\
\text { Magban } \\
\end{array}$ & $\begin{array}{c}(5) \\
\text { Szár+mag }\end{array}$ & \multirow{2}{*}{$\begin{array}{c}(6) \\
\text { Összesen } \\
\text { 1996-ban }\end{array}$} \\
\hline & & \multicolumn{3}{|c|}{ júl. 23-án } & \\
\hline As & 3 & 8 & 1 & 9 & 12 \\
\hline $\mathrm{Pb}$ & 4 & 6 & 0 & 6 & 10 \\
\hline $\mathrm{Ni}$ & 10 & 7 & 7 & 14 & 24 \\
\hline $\mathrm{Hg}$ & 31 & 2 & 0 & 2 & 33 \\
\hline $\mathrm{Cr}$ & 48 & 19 & 9 & 28 & 76 \\
\hline $\mathrm{Cu}$ & 51 & 13 & 25 & 38 & 89 \\
\hline $\mathrm{Ba}$ & 90 & 52 & 16 & 68 & 158 \\
\hline $\mathrm{Cd}$ & 136 & 37 & 20 & 57 & 193 \\
\hline $\mathrm{Zn}$ & 643 & 105 & 168 & 273 & 916 \\
\hline $\mathrm{Al}$ & 900 & 432 & 50 & 482 & 1382 \\
\hline $\mathrm{Sr}$ & 1174 & 680 & 249 & 929 & 2103 \\
\hline $\mathrm{Se}$ & 1482 & 126 & 189 & 315 & 1797 \\
\hline Mo & 1639 & 330 & 240 & 570 & 2209 \\
\hline
\end{tabular}

Megjegyzés: A mag csírázóképessége átlagosan $80 \%$ volt és igazolhatóan nem módosult a kezelések hatására. Az 1000-mag tömege 12 g volt átlagosan, a $810 \mathrm{~kg} / \mathrm{ha}$ Askezelésben igazolhatóan 8 g-ra csökkent

A második csoportot a króm, réz, bárium és kadmium képezi, melyek tömege 76-193 g/ha között alakult. A Zn 0,9 kg, Al 1,4 kg, Se 1,8 kg, Sr 2,1 kg, Mo 2,2 kg mennyiséget ért el az összes föld feletti 7,7 t/ha légszáraz termésben. A viszonylag nagy elemfelvételek ellenére a terheléshez viszonyítva nem jelenthet reális alternatívát a talajtisztítás számára a fitoremediáció. Még a maximumot mutató molibdén esetén is legkevesebb 300 évre volna szükség a 810 $\mathrm{kg} / \mathrm{ha}$ terhelésü talaj elszegényítéséhez.

\section{Összefoglalás}

Löszön képződött vályog mechanikai összetételü karbonátos csernozjom talajon, az MTA Talajtani és Agrokémiai Kutatóintézet Nagyhörcsöki Kísérleti Telepén szabadföldi kisparcellás mikroelem-terhelési kísérletet állítottunk be 1991 tavaszán. A termőhely talajának szántott rétege mintegy $5 \% \mathrm{CaCO}_{3}$-ot és $3 \%$ humuszt tartalmazott, felvehető tápelemekkel való ellátottsága: $\mathrm{Ca}, \mathrm{Mg}$, $\mathrm{Mn}, \mathrm{Cu}$ kielégítő, $\mathrm{N}$ és $\mathrm{K}$ közepes, $\mathrm{P}$ és $\mathrm{Zn}$ gyenge volt. A talajvíz $15 \mathrm{~m}$ mélyen helyezkedik el, a terület vízmérlege negatív, aszályra hajló. A 13 vizsgált 
mikroelem sóit 4-4 szinten alkalmaztuk 1991 tavaszán, a kukorica vetése előtt. A 13 x $4=52$ kezelést 2 ismétlésben állítottuk be, összesen 104 parcellán, splitplot elrendezésben. A terhelési szintek $0,90,270,810 \mathrm{~kg} / \mathrm{ha}$ mennyiséget jelentettek elemenként $\mathrm{AlCl}_{3}, \mathrm{NaAsO}_{2}, \mathrm{BaCl}_{2}, \mathrm{CdSO}_{4}, \mathrm{~K}_{2} \mathrm{CrO}_{4}, \mathrm{CuSO}_{4}, \mathrm{HgCl}_{2}$, $\left(\mathrm{NH}_{4}\right)_{6} \mathrm{Mo}_{7} \mathrm{O}_{24}, \mathrm{NiSO}_{4}, \mathrm{~Pb}\left(\mathrm{NO}_{3}\right)_{2}, \mathrm{Na}_{2} \mathrm{SeO}_{3}, \mathrm{SrSO}_{4}$ és $\mathrm{ZnSO}_{4}$ formájában. A 100-100-100 kg/ha N- $\mathrm{P}_{2} \mathrm{O}_{5} \mathrm{~K}_{2} \mathrm{O}$ alaptrágyázás egységesen történt az egész kísérletben ammonnitrát-, szuperfoszfát- és kálisómütrágyákkal. A növényi sorrend kukorica, sárgarépa, burgonya, borsó és cékla volt. A 6. évben végzett spenót kísérletünk eredményeit az alábbiakban foglaljuk össze:

- A 13 vizsgált elemből az As, Cd és Se bizonyult toxikusnak a spenótra. A gyomirtó kapálás előtti gyomborítottság \%-át viszont igazolhatóan az As-, Crés Se-terhelés mérsékelte.

- A zöld levéltermés június 3-án 18 t/ha mennyiséget tett ki átlagosan a kontrolltalajon, mely a maximális As-terheléssel $10 \mathrm{t} / \mathrm{ha}$, Cd-terheléssel $4 \mathrm{t} / \mathrm{ha}$ mennyiségre csökkent. A 270, ill. $810 \mathrm{~kg} / \mathrm{ha}$ Se-kezelésekben a növények kipusztultak. A július 23-án betakarított légszáraz szár 2,5 t/ha, míg a mag 2,8-3,0 t/ha hozamot adott a szennyezetlen talajon. A $810 \mathrm{~kg} / \mathrm{ha}$ As-kezelésben a maghozam 1,6 t/ha-ra esett, míg a hasonló terhelésü Cd-kezelésben értékelhető termést már nem kaptunk.

- Elsősorban a zöld levél dúsult szennyező elemekben, kevésbé a szár, ill. legkevésbé a mag. Mérsékelt (10 mg/kg alatti maximális) koncentrációban fordult elő az arzén, higany, magnézium, nikkel és ólom. A bárium, króm és réz 20-40 mg/kg, a kadmium 144, a cink 289, a stroncium 518, a molibdén 670 és a szelén $765 \mathrm{mg} / \mathrm{kg}$ koncentrációt ért el a légszáraz levélben. A három nagyságrendbeli dúsulás (hiperakkumuláció) a Mo és Se elemekre volt jellemző, melyek tömegárammal akadálytalanul bejuthatnak a föld feletti növényi részekbe. A molibdenát- és szelenátanionok felvehetők maradnak ezen a meszes, jól szellőzött talajon hosszú éveken át.

- A zöld spenótlevél klorofill-A- és klorofill-A'-tartalma igazolhatóan nőtt a Cr- és Se-kezelésekben. A Se-terhelés drasztikusan emelte a klorofill-B és klorofill-B' frakciók mennyiségét, míg a Cr-szennyezett talajon a klorofill-B forma klorofill-B' formává alakult át.

- A karotinoidok közül a lutein mennyisége megkétszereződött a Se-kezelésben, valamint a $\beta$-karotin-tartalma megtöbbszöröződött a Cr- és Se-terheléssel. A $\beta$-tokoferol koncentrációját mind az As-, mind a Cr- és Se-szennyezés mérsékelte.

- A 17-19 t/ha friss levéltermés (2,2 t/ha légszáraz tömeg) $84 \mathrm{~kg} \mathrm{~K}-, 58 \mathrm{~kg}$ N-, $51 \mathrm{~kg} \mathrm{Ca-}, 12 \mathrm{~kg} \mathrm{Mg}$-, 7-9 kg S- és P-készlettel rendelkezett. A $10 \mathrm{t}$ zöld levéltermésre számított elemigény $32 \mathrm{~kg} \mathrm{~N}, 9 \mathrm{~kg} \mathrm{P}_{2} \mathrm{O}_{5}, 56 \mathrm{~kg} \mathrm{~K}_{2} \mathrm{O}$ ezen a talajon, amennyiben a melléktermést leszántjuk. A 7,7 t/ha összes föld feletti lég-

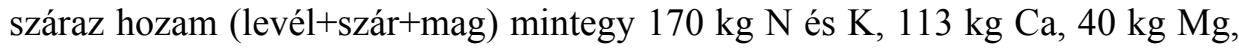


22-24 kg S és P elemakkumulációt mutatott. A felvett Fe-, Al- és Mn-menynyiség $0,8-1,5 \mathrm{~kg}$ között ingadozott.

- A szennyezett talajon mért maximális mikroelem-felvételek az alábbiak voltak a spenót összes föld feletti termésében: $\mathrm{As}, \mathrm{Pb}, \mathrm{Ni}, \mathrm{Hg} 12-33 \mathrm{~g} / \mathrm{ha}$ között; Cr, Cu, Ba, Cd 76-193 g/ha között; Zn 0,9 kg/ha, Al 1,4 kg/ha, Se 1,8 kg/ ha, $\mathrm{Sr} 2,1 \mathrm{~kg} / \mathrm{ha}$, ill. Mo 2,2 kg/ha. Az erősen szennyezett talajok tisztítására a fitoremediáció nem jelenthet reális alternatívát. A $810 \mathrm{~kg} / \mathrm{ha}$ terhelésnél még a maximális felvételt adó molibdén esetén is legkevesebb 300 évre volna szükség az eredeti állapot helyreállításához hasonló körülmények között.

\section{Irodalom}

BALÁzS S. (Szerk.) 1994. Zöldségtermesztők kézikönyve. 2. jav. kiadás. Mezőgazda Kiadó. Budapest.

BERGMANN, W., 1988. Ernährungsstörungen bei Kulturpflanzen. VEB Gustav Fischer Verlag. Jena.

BIACS, P. A. \& DAOOD, H. G., 1994. High-performance liquid chromatography with photodiode-array detection of carotenoids and carotenoid esters in fruits and vegetables. J. Plant Physiol. 143. 520-525.

BingHAM, F. T. et al., 1975. Growth and cadmium accumulation of plants grown on a soil treated with cadmium-enriched sewage sludge. J. Environ. Qual. 4. 207-211.

CselöTEI L., NYÚJTÓ S. \& CSÁKY A., 1993. Kertészet. 5. átdolg. kiadás. Mezőgazda Kiadó. Budapest.

FiLıUS I., 1994. A zöldségnövények tápanyagai. In: Zöldségtermesztők kézikönyve. (Szerk.: BALÁZs S.) 2. jav. kiadás. 73-94. Mezőgazda Kiadó. Budapest.

KÁDÁR I., KONCZ J. \& RADICS L., 2001. Mikroelem-terhelés hatása a céklára karbonátos csernozjom talajon. Agrokémia és Talajtan. 50. 315-334.

KÁDÁR I., RADICS L. \& BANA K-NÉ, 2000. Mikroelem-terhelés hatása a kukoricára karbonátos csernozjom talajon. Agrokémia és Talajtan. 49. 181-204.

LAKANEN, E. \& ERVIÖ, R., 1971. A comparison of eight extractants for the determination of plant available micronutrients in soils. Acta Agr. Fenn. 123. 223-232.

LehoczKy, É., Szabados, I. \& MARTH, P., 1996. Cadmium content of plants as affected by soil cadmium concentration. In: Soil and Plant Analysis in Sustainable Agriculture and Environment. (Eds.: HoOD, T. M. \& JONES, J. B.) 827-839. Marcel Dekker, Inc. New York.

LEHOCZKY, É. et al., 1998. Effect of liming on the heavy metal uptake of lettuce. Agrokémia és Talajtan. 47. 229-234.

MARSCHNER, H., 1985. Einfluss von Standort und Wirtschaftsbedingungen auf die Nitratgehalte in verschiedenen Pflanzenarten. Landw. Forsch. Sonderh. 16-23.

SAUERBECK, D., 1982. Welche Schwermetallgehalte in Pflanzen dürfen nicht überschritten werden, um Wachstumsbeeinträchtigungen zu vermeiden? Landw. Forsch., Sh. 39.108-129. 
SAUERBECK, D., 1991. Plant, element and soil properties governing uptake and availability of heavy metals derived from sewage sludge. Water, Air, Soil Pollut. 5758. $227-237$.

SIMON L., 1998. Talajszennyezés, talajtisztítás. GATE Mezőgazd. Főiskolai Kara. Nyíregyháza.

Terbe I., 1994. Spenót. In: Zöldségtermesztők kézikönyve. (Szerk.: BALÁzs S.) 2. jav. kiadás. 571-576. Mezőgazda Kiadó. Budapest.

VerloO, M. \& WillaerT, G., 1990. Direct and indirect effect of fertilization practices on heavy metals in plants and soils. In: Fertilization and the Environment. (Eds: MerCKX H. et al.) 79-87. Leuven Univ. Press. Belgium.

Érkezett: 2001. április 17. 


\title{
Effect of Microelement Loads on Spinach Grown on Calcareous Chernozem Soil
}

\author{
${ }^{1}$ I. KÁDÁR, ${ }^{2}$ H. DAOOD and ${ }^{3}$ L. RADICS \\ ${ }^{1}$ Research Institute for Soil Science and Agricultural Chemistry of the Hungarian Academy of \\ Sciences, Budapest; ${ }^{2}$ Lipid Laboratory, Central Institute for Food Industry Research, Budapest \\ and ${ }^{3}$ Faculty of Horticultural Science, Szent István University, Budapest
}

\section{Summary}

The small-plot field experiment set up in spring 1991 (soil characteristics, groundwater depth, the form and level of applied microelement treatments, crop sequence) was described in KÁDÁR et al. (2001). The results of the spinach experiment carried out in the $6^{\text {th }}$ year can be summarized as follows:

- Of the 13 elements examined, As, $\mathrm{Cd}$ and Se proved to be toxic to spinach, but the $\%$ weed cover prior to hoeing for weed control significantly moderated the $\mathrm{As}, \mathrm{Cr}$ and Se pollution.

- On Jun. $3^{\text {rd }}$ the green leaf yield averaged $18 \mathrm{t} / \mathrm{ha}$ on the control soil, which was reduced to $10 \mathrm{t} / \mathrm{ha}$ by maximum As loads and to $4 \mathrm{t} / \mathrm{ha}$ by Cd. In the 270 and $810 \mathrm{~kg} / \mathrm{ha}$ Se treatments the plants were all destroyed. The air-dry stems harvested on Jul. $23^{\text {rd }}$ amounted to $2.5 \mathrm{t} / \mathrm{ha}$ and the seed to $2.8-3.0 \mathrm{t} / \mathrm{ha}$ on untreated soil. In the $810 \mathrm{~kg} / \mathrm{ha}$ As treatment the seed yield dropped to $1.6 \mathrm{t} / \mathrm{ha}$, while in the maximum $\mathrm{Cd}$ treatment there was no evaluable yield.

- The microelements accumulated mainly in the green leaves, to a lesser extent in the stems and least of all in the seed. Moderate maximum concentrations of less than 10 $\mathrm{mg} / \mathrm{kg}$ were found in the air-dry leaves for $\mathrm{As}, \mathrm{Hg}, \mathrm{Mg}, \mathrm{Ni}$ and $\mathrm{Pb}$, while $\mathrm{Ba}, \mathrm{Cr}$ and $\mathrm{Cu}$ reached concentrations of 20-40, Cd 144, Zn 289, Sr 518, Mo 670 and Se $765 \mathrm{mg} / \mathrm{kg}$, resp. Hyperaccumulation, with increases of three orders of magnitude, was characteristic of Mo and S. The molybdenate and selenate anions remain available for many years in this calcareous, well-aerated soil.

- The chlorophyll-A and chlorophyll-A' contents of the green spinach leaves rose significantly in the $\mathrm{Cr}$ and $\mathrm{Se}$ treatments. Se loads led to a drastic increase in the chlorophyll-B and chlorophyll-B' fractions, while on soil contaminated with $\mathrm{Cr}$ the chlorophyll-B form was converted to chlorophyll-B'.

- Among the carotinoids, the quantity of lutein was doubled in the Se treatment, the $\beta$-carotene content became many times greater in the $\mathrm{Cr}$ and $\mathrm{Se}$ treatments. The $\beta$ tocopherol concentration was reduced by $\mathrm{As}, \mathrm{Cr}$ and Se loads.

- The 17-19 t/ha fresh leaf yield (2.2 t/ha air-dry mass) contained $84 \mathrm{~kg} \mathrm{~K}, 58 \mathrm{~kg} \mathrm{~N}$, $51 \mathrm{~kg} \mathrm{Ca}, 12 \mathrm{~kg} \mathrm{Mg}$, and 7-9 $\mathrm{kg} \mathrm{S}$ and $\mathrm{P}$. The element requirements calculated for a green leaf yield of $10 \mathrm{t} / \mathrm{ha}$ were $32 \mathrm{~kg} \mathrm{~N}, 9 \mathrm{~kg} \mathrm{P}_{2} \mathrm{O}_{5}$ and $56 \mathrm{~kg} \mathrm{~K}_{2} \mathrm{O}$ on this soil, provided the by-products were incorporated. The $7.7 \mathrm{t} / \mathrm{ha}$ total aboveground dry yield (leaf+stem+seed) exhibited an element accumulation of $170 \mathrm{~kg} \mathrm{~N}$ and K, $113 \mathrm{~kg} \mathrm{Ca}$, $40 \mathrm{~kg} \mathrm{Mg}$ and 22-24 $\mathrm{kg} \mathrm{S}$ and $\mathrm{P}$. The uptake of $\mathrm{Fe}, \mathrm{Al}$ and $\mathrm{Mn}$ was $0.8-1.5 \mathrm{~kg}$.

- The maximum microelement uptake recorded on treated soil in the total aboveground yield of spinach amounted to $12-33 \mathrm{~g} / \mathrm{ha}$ for As, $\mathrm{Pb}, \mathrm{Ni}$ and $\mathrm{Hg}, 76-193 \mathrm{~g} / \mathrm{ha}$ for $\mathrm{Cr}, \mathrm{Cu}, \mathrm{Ba}$ and $\mathrm{Cd}, 0.9 \mathrm{~kg} / \mathrm{ha}$ for $\mathrm{Zn}, 1.4$ for Al, 1.8 for Se, 2.1 for Sr and $2.2 \mathrm{~kg} / \mathrm{ha}$, 
resp. for Mo. Phytoremediation is not a real alternative for the cleansing of heavily contaminated soil. At a pollution level of $810 \mathrm{~kg} / \mathrm{ha}$ at least 300 years would be required under these conditions for the re-establishment of the original state even in the case of Mo, where the maximum uptake was recorded.

Table 1. Agronomic measures and observations in the spinach experiment (Calcareous chernozem soil, Nagyhörcsök, 1995-1996).

Table 2. Effect of treatments causing phytotoxicity on plant cover (Calcareous chernozem soil, Nagyhörcsök, May 12 ${ }^{\text {th }} 1996$ ). (1) Element. (2) Loads in spring 1991, $\mathrm{kg} /$ ha. (3) $\mathrm{LSD}_{5 \%}$. (4) Mean. A. \% spinach cover. B. \% weed cover. C. Total cover. D. $\%$ cover with Amaranthus blitoides.

Table 3. Effect of toxic elements causing yield losses in spinach (Calcareous chernozem soil, Nagyhörcsök, 1996). (1)-(4): see Table 2. A. Mean plant height on Jun. $3^{\text {rd }}$, $\mathrm{cm}$. B. Scoring for plant stand on Jul. $23^{\text {rd }}$. C. Green leaf yield on Jun. $3^{\text {rd }}, \mathrm{t} / \mathrm{ha} . \quad$ D. Air-dry stem yield on Jul. $23^{\text {rd }}$, t/ha. E. Air-dry seed yield on Jul. $23^{\text {rd }}$, t/ha. Note: *Scoring: $0=$ plants destroyed, $1=$ poorly, $5=$ well developed stand. $* *$ The leaf yield represented $80-85 \%$ of the aboveground mass. Air-dry matter $12 \%$, mean air-dry matter yield on untreated soil $2.2 \mathrm{t} / \mathrm{ha}$.

Table 4. Effect of loads on the element content of air-dry spinach, 1996. (1) Plant organ. a) leaf, b) stem, c) seed. (2)-(4): see Table 2. A-L. As a result of As, Ba, Cd, Cr, $\mathrm{Cu}, \mathrm{Hg}, \mathrm{Mo}, \mathrm{Ni}, \mathrm{Pb}, \mathrm{Se}, \mathrm{Sr}$ and $\mathrm{Zn}$ loads, resp., $\mathrm{mg} / \mathrm{kg}$. Note: ${ }^{1}:$ on Jun. $3^{\text {rd }},{ }^{2}$ : at harvest, Jul. $23^{\text {rd }}$; the $\mathrm{As}, \mathrm{Hg}$, Mo and $\mathrm{Pb}$ concentrations were below $0.1 \mathrm{mg} / \mathrm{kg}$ on untreated soil.

Table 5. Effect of phytotoxic treatments on the chlorophyll content of fresh spinach leaves (Calcareous chernozem soil, Nagyhörcsök, Jun. $\left.3^{\text {rd }} 1996\right)$. (1)-(4): see Table 2.

Table 6. Effect of phytotoxic treatments on the lutein, $\beta$-carotene and $\beta$-tocopherol contents of fresh spinach leaves (Calcareous chernozem soil, Nagyh $\varphi r c s \varphi k$, Jun. $3^{\text {rd }}$ 1996). (1)-(4): see Table 2.

Table 7. Mean composition of air-dry spinach on untreated soil (Calcareous chernozem soil, Nagyhörcsök, 1996). (1) Element. (2) Units. (3) Leaves on Jun. $3^{\text {rd }}$. (4) Stem on Jul. $23^{\text {rd }}$. (5) Seed on Jul. $23^{\text {rd }}$. Note: As, Hg and Mo values were below the detection limit. Leaf optima according to BERGMANN (1988).

Table 8. Element uptake of the aboveground air-dry yield of spinach on untreated soil (Calcareous chernozem soil, Nagyhörcsök, 1996). (1) Element. (2) Units. (3) In the leaf, $2.2 \mathrm{t} / \mathrm{ha}$. (4) In the stem, $2.5 \mathrm{t} / \mathrm{ha}$. (5) In the seed, $3.0 \mathrm{t} / \mathrm{ha}$. (6) Total, $7.7 \mathrm{t} / \mathrm{ha}$. Note: $\mathrm{As}, \mathrm{Hg}$ and Mo values were below the detection limit. Element requirements of $10 \mathrm{t}$ fresh leaf yield.

Table 9. Maximum microelement uptake of spinach on contaminated soil, g/ha (Calcareous chernozem soil, Nagyhörcsök) (1) Element. (2) In the leaf on Jun. $3^{\text {rd }}$. (3) In the stem, (4) In the seed, (5) In the stem+seed on Jul. 23 ${ }^{\text {rd }}$. (6) Total in 1996. Note: Seed germination ability averaged $80 \%$ and was not significantly influenced by the treatments. The 1000-seed mass averaged $12 \mathrm{~g}$, and decreased significantly to $8 \mathrm{~g}$ in the $810 \mathrm{~kg} / \mathrm{ha}$ As treatment. 